\title{
Corporate Governance and Strategic Management Accounting Disclosure
}

\section{Setianingtyas Honggowati', Rahmawati Rahmawati', Y. Anni Aryani', and Agung Nur Probohudono'}

\author{
${ }^{1}$ Universitas Sebelas Maret, Department of Accounting, Surakarta, Indonesia \\ *Correspondence to: Setianingtyas Honggowati, Universitas Sebelas Maret, \\ Department of Accounting, Jalan Ir. Sutami No. 36A, Kentingan, Surakarta 57126, \\ Indonesia. \\ E-mail: setianingtyas_27@yahoo.co.id
}

\begin{abstract}
The aim of this study is to examine the corporate governance influence on strategic management accounting disclosure. The strategic management accounting disclosure in this study was measured by the disclosure level regarding strategic management accounting published in the company's annual report according to the index (made by the author). The corporate governance is proxied by board size, independent board, and managerial ownership. The data of this study are 497 manufacturing companies in Indonesia in the period of 2011-2015 and the method employed in this study is regression analysis method. The findings show that board size has significant positive influence on the disclosure level of strategic management accounting of manufacturing companies in Indonesia, and the proportion of independent board does not influence SMA disclosure, while managerial ownership has negative influence the disclosure level of strategic management accounting.
\end{abstract}

Keywords: strategic management accounting disclosure, board size, independent board, managerial ownership, firm size, profitability, leverage.

Article info: Received 4 February 2017; revised 27 February 2017; accepted 2 March 2017

Recommended citation: Honggowati, S., Rahmawati, R., Aryani, Y. A., \& Probohudono, A. N. (2017). Corporate Governance and Strategic Management Accounting Disclosure. Indonesian Journal of Sustainability Accounting and Management, 1(1), 23-30.

DOI: 10.28992/ijsam.v111.24

\section{Introduction}

In the increasingly competitive business environment, companies are required to utilize all of their resources to pursue competitive advantage. Company strategic management is a way to gain sustainable competitive advantage through resource management (resource-based view) and the ability to adapt and maintain relationships with stakeholders (Nixon \& Burns, 2012).

Companies need to seek information that potentially can be used as primary analytical tools related to market share, cost competitors and sales volume. Strategic information is crucial for senior managers to manage their companies' resources with strategic opportunities to achieve competitive advantage (Dixon \& Smith, 1993). Knowledge regarding competitor's costs allows companies to identify whether competitors may change their position in the market, therefore, the company can formulate strategy through price manipulation. Knowledge regarding market share and cost structure has influence in the decision making 
process to respond to the competitors' actions. Strategic Management Accounting (SMA) expands the role of management accounting by combining other information related to the company's activities (Dixon \& Smith, 1993). Thus, the application of SMA in the company is to develop, monitor and evaluate the applied business strategy.

Starting from Simmonds (1981), SMA has been known for more than three decades. However, there has been not been any comprehensive agreement regarding the definition of SMA (Cadez \& Guilding, 2008; Cinquini \& Tenucci, 2007; Juras, 2014). Although the substantial growth regarding SMA literatures has not achieved a definitive agreement, Cadez \& Guilding (2008) state 1) that there has been limited consensus related to the definition of SMA, 2) and that SMA is of considerable concern, but the empirical research related SMA is still rare, and most researches so far only focused on the use of SMA techniques. Most of SMA empirical research used survey and interview techniques in reviewing the level of SMA implementation (AIMaryani \& Sadik, 2012; Cadez \& Guilding, 2008; Cinquini \& Tenucci, 2007; Fowzia, 2011; Roslender \& Hart, 2002).

Agency theory is a concept that describes the contractual relationship between principle and agents. The Principle Party is the party that gives mandate to the other party, the agent, to do all activities on the behalf of the principals in their capacity as decision-makers (Jensen \& Meckling, 1976). A principal is motivated to sign a contract with the agent, if that aims to bring prosperity for himself or herself by constantly increasing his or her company's profitability (Rahmawati et al., 2015). According to Probohudono (2012), conceptual framework of agency theory presents the ideal mechanism in assessing the disclosure practices conducted by the manufacturing companies because manufacture companies perform more frequent rotations in order to the develop organizational culture to reduce agency problems. In addition, the agency theory makes it is easier to monitor company's performance. A number of studies have provided empirical evidence that disclosure has a significant ability to reduce information asymmetry.

SMA is often defined as the use of financial and non-financial accounting information to support strategic decision making (Tillmann \& Goddard, 2008). Compared with the conventional accounting management, SMA has externally oriented perspective (Bromwich, 1990; Cadez \& Guilding, 2008; Roslender \& Hart, 2002). Therefore, broader disclosure of SMA in the company's financial statements will assist stakeholders in making decisions. In this study, SMA Disclosure is measured by using disclosure index study based on the GRI4.

Agency conflicts can be resolved by the board of directors including independent board. Meanwhile, the number of board of directors in the company has influence on the company performance (Cormier et al., 2010). This is because the board of directors, as the representative of shareholders, performs the monitoring task including monitoring risk management. According to the agency theory, the presence of directors is expected to oversee the management and protect the shareholders' interests (Fama \& Jensen, 1983).

In this study, corporate governance mechanism is measured through the board of director size, the proportion of independent board, and the managerial ownership. The Board of Directors is one of the most important elements in the corporate governance mechanisms (Suteja \& Gunardi, 2016). The board plays the role of overseeing the implementation of the company's activities managed as well as possible by the general managers (Said et al., 2009). Meanwhile, good governance structure can be formed by independent board through transparent disclosure and in effective legal environment that would reduce the potentially dysfunctional behavior of the controlling shareholder (Yuen et al., 2010).

Managerial ownership is the active owner in the company management who takes part in the decision making process. Greater proportion of managerial ownership will influence the management to work harder to represent the interests of the owner who is none other than himself. With more strategies implemented by the company, the tendency to disclose more information to the public shall also increase. Thus, there is a positive relationship between managerial ownership and disclosure (Nagar et al., 2003; Probohudono, 2012; Probohudono et al., 2014). Greater proportion of managerial ownership will cause more disclosure of company 
information (Jiang \& Habib, 2009; Vu et al., 2011). However, these findings are in the opposite direction to the research results of Akhtaruddin \& Haron (2010) and Samaha \& Dahawy (2011) which conclude that managerial ownership has negative influence on corporate disclosures (Guan et al., 2007; Huafang \& Jianguo, 2007).

The authors' study on the previous researches shows that there has not been any research on SMA Disclosure in the annual report. Therefore, the authors are motivated to reduce the gap by conducting research on SMA Disclosure in the company's annual report. This study aims to examine the influence of corporate governance mechanism on the disclosure level of company's strategic management accounting. The strategic Management Accounting disclosure level is measured by using disclosure index study based on the GRI Index (formulated by the authors). The samples in this study are manufacturing companies listed in the Indonesian Stock Exchange (IDX) in the years of 2011-2015.

\section{Methods}

This research is a quantitative research, and the data used are secondary data derived from company financial statements. This study uses samples of manufacturing companies listed in Indonesia Stock Exchange in the periods of 2011-2015. This study uses purposive sampling technique in determining the samples. Samples that match the criteria required by the researcher are 107 companies.

Samples that match the criteria proposed by researchers are 535 observations. After the data selection process, 38 data have extreme value and should be excluded from the sample. Therefore, the total numbers of data that can be analyzed are 497 corporate data.

Table 1 Sample Size

\begin{tabular}{lc}
\hline \multicolumn{1}{c}{ Description } & Total \\
\hline Manufacturing companies listed in the years 2011-2015 & 115 \\
The Companies do not present complete financial reports for 2011-2015 & $(7)$ \\
The number of companies suitable sample & 107 \\
\hline
\end{tabular}

The dependent variables are the voluntary disclosures of SMA index compiled by researchers through the following stages:

- Identifying the elements of SMA definition from the results of the research conducted by (Bromwich, 1990; Hoque, 2006; Http://www.cimaglobal.com/, 2005; Langfield-Smith, 2008; Ma \& Tayles, 2009; Roslender \& Hart, 2002; Shank, 1989; Simmonds, 1981; Ward, 1992).

- $\quad$ Tracing all indicators on GRI4 which are suitable with SMA elements.

- Reorganizing the indicators on GRI4 as the reporting quality in accordance with the elements of SMA definition as the SMA disclosure Index.

The independent variables in this study were measured through the mechanism of corporate governance board size, the proportion of independent board and managerial ownership. The control variables used in this study are: the company size, profitability and leverage, in order to control the effect of independent variables on the dependent variables so that they are not influenced by the external factors. The data analysis method used in this study is multiple regression equation models to identify the influence of independent variables on the dependent variables. 


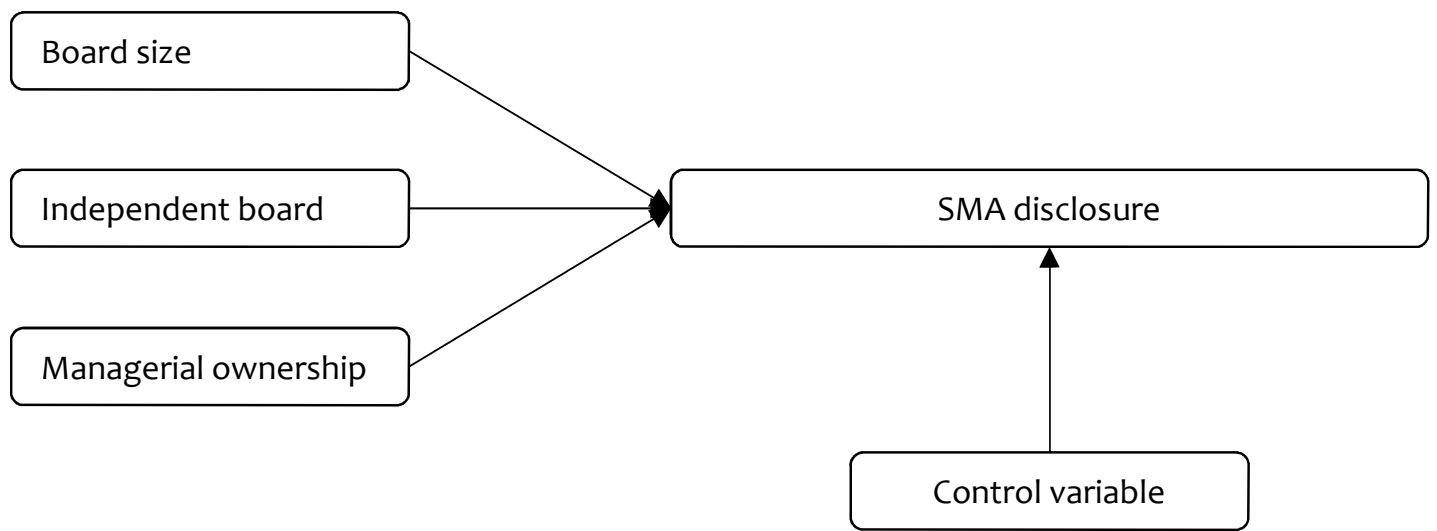

Figure 1 Research Framework

In accordance with the research framework, the regression equation as follows:

$$
S M A D=\alpha+B_{1} B_{i t}+B_{2} I B_{i t}+B_{3} M O_{i t}+B_{4} S I Z E_{i t}+B_{5} P_{R O F I T}+B_{6} L E V_{i t}+\varepsilon_{i t}
$$

Information:

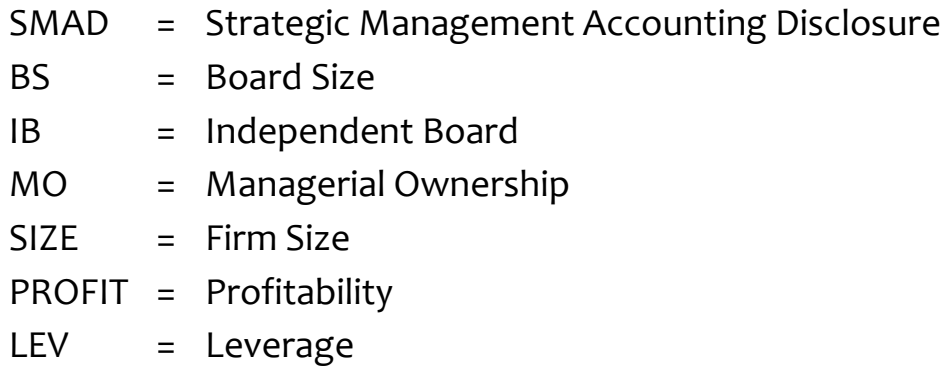

Table 2 Summary of Research Variable

\begin{tabular}{lcc}
\hline \multicolumn{1}{c}{ Variable } & Code & Measurement \\
\hline Dependent & SMAD & $\frac{\sum \text { Score of SMAD }}{\text { Total SMAD }}$ \\
Independent & BS & Board of Commissioners \\
Independent & IB & $\frac{\text { Independent Commissioners }}{\text { Board of Commissioners }}$ \\
Independent & MO & $\frac{\text { Total of Managerial shares }}{\text { Total of outstanding shares }}$ \\
Control & SIZE & Ln (Total Assets) \\
Control & PROFIT & $\frac{\text { Net Income }}{\text { Total Assets }}$ \\
Control & LEV & $\frac{\text { Total Debt }}{\text { Total Equity }}$ \\
\hline
\end{tabular}




\section{Results and Discussion}

All data used in this study have been through classical assumption test. The linear regression test results are presented in Table 3. Regarding the Board of Directors' influence on SMA disclosure, this study proves that the board size has influence on the extent of SMA disclosure. This can be seen in Table 3, which shows that the board size significance value is less than $0.05(0.000<0.05)$, thus H1a is accepted.

Table 3 Summary of Hypotheses Testing

\begin{tabular}{|c|c|c|c|c|}
\hline Variable & Exp. Sig. & Coefficient & $t$ & Sig. \\
\hline BS & + & 0.0043 & 0.129 & $0.012 *$ \\
\hline IB & + & 0.0067 & 1.014 & 0.745 \\
\hline MO & + & -0.0006 & -2.565 & $0.011^{*}$ \\
\hline SIZE & $\mathrm{N} / \mathrm{A}$ & 0.0080 & 4.040 & $0.000 *$ \\
\hline PROFIT & $\mathrm{N} / \mathrm{A}$ & 0.1404 & 5.511 & $0.000 *$ \\
\hline LEV & $\mathrm{N} / \mathrm{A}$ & 0.0012 & 0.600 & 0.549 \\
\hline Adjusted R2 & & 0.174 & & \\
\hline F-Value & & 18.456 & & \\
\hline P-Value & & 0.000 & & \\
\hline
\end{tabular}

*significant at level $5 \%$

Source: Processed Secondary Data, 2016

Regarding the proportion of independent board's influence on SMA disclosure, the results show that it does not affect the SMA disclosure in Indonesian companies. In Table 3, the significant value of independent board size is greater than 0.05 (0.745> 0.05), thus, $\mathrm{H} 1 \mathrm{~b}$ is rejected. This is likely because the number of independent board is relatively less than the non-independent commissioners. Furthermore, one of the common characteristics of Indonesian company is that the share of ownership is mostly dominated by family members or their trusted subordinate. The family members and the trusted subordinate usually hold the director or commissioner positions and interfere with the decision making process. Thus, independent board of directors in Indonesian company is not the effective form of control (Lukviarman, 2001).

Regarding managerial ownership, this study proves that managerial ownership has negative influence on the extent of SMA (H1C rejected). This indicates that with larger proportion of managerial ownership in Indonesian manufacturing company, the companies' voluntary SMA disclosure level is lower because SMA is considered as classified information and should not be disclosed to the management and shareholder. This result is in line with previous research conducted by Akhtaruddin \& Haron (2010) and Samaha \& Dahawy (2011), Huafang \& Jianguo (2007) and Guan et al., (2007) which state that managerial ownership has negative influence to corporate disclosure. 


\section{Conclusion}

This study empirically examined the influence of corporate governance mechanism on SMA disclosure of manufacturing companies in Indonesia. Corporate governance mechanism as measured by the board of directors' size has significant positive influence on the disclosure of strategic management accounting of manufacturing company in Indonesia. On the other hand, the proportion of independent board does not have influence but and managerial ownership has a negative influence on the SMA disclosure of manufacturing company in Indonesia.

This study has limitations in term of data samples which only uses manufacturing companies listed in the Indonesia Stock Exchange, thus the results of this study cannot be generalized to all companies in Indonesia. And the strategic management accounting measurement method only uses GRI4 as the base to formulate index, thus it is less comprehensive. Therefore, future research can consider other index to be combined in the SMA disclosure index, such as from previous articles attempting to identify voluntary disclosure which can be attributed to strategic management accounting.

\section{References}

Akhtaruddin, M., \& Haron, H. (2010). Board ownership, audit committees' effectiveness, and corporate voluntary disclosures. Asian Review of Accounting, 18(3), 245-259. http://doi.org/10.1108/13217341011089649

AlMaryani, M. A. H., \& Sadik, H. H. (2012). Strategic Management Accounting Techniques in Romanian Companies: Some Survey Evidence. Procedia Economics and Finance, 3, 387-396. http://doi.org/10.1016/S2212-5671(12)00169-4

Bromwich, M. (1990). The case for strategic management accounting: The role of accounting information for strategy in competitive markets. Accounting, Organizations and Society, 15(1-2), 27-46. http://doi.org/10.1016/0361-3682(90)90011-I

Cadez, S., \& Guilding, C. (2008). An exploratory investigation of an integrated contingency model of strategic management accounting. Accounting, Organizations and Society, 33(7-8), 836-863. http://doi.org/10.1016/j.aos.2008.01.003

Cinquini, L., \& Tenucci, A. (2007). Is the adoption of Strategic Management Accounting techniques really "strategy-driven"? Evidence from a survey (Munich Personal RePEc Archive No. 11819).

Cormier, D., Ledoux, M., Magnan, M., \& Aerts, W. (2010). Corporate governance and information asymmetry between managers and investors. Corporate Governance: The International Journal of Business in Society, 10(5), 574-589. http://doi.org/10.1108/14720701011085553

Dixon, R., \& Smith, D. (1993). Strategic management accounting. Omega, 21(6), 605-618. http://doi.org/10.1016/0305-0483(93)90003-4

Fama, E. F., \& Jensen, M. C. (1983). Separation of Ownership and Control. The Journal of Law and Economics, 26(2), 301-325. http://doi.org/10.1086/467037

Fowzia, R. (2011). Strategic Management Accounting Techniques: Relationship with Business Strategy and Strategic Effectiveness of Manufacturing Organizations in Bangladesh. World Journal of Management, 3(2), 54-69.

Guan, Y.-D., Sheu, D.-F., \& Chu, Y.-C. (2007). Ownership Structure, Board of Directors, and Information Disclosure: Empirical Evidence from Taiwan IC Design Companies. The Journal of American Academy of Business, 11(2), 182-190.

Hoque, Z. (2006). Strategic management accounting (2nd ed.). Pearson Australia. 
Http://www.cimaglobal.com/. (2005). Management accounting in support of the strategic management $\begin{array}{lllll}\text { process. } & \text { Retrieved January } & 12, & \text { 2017, from }\end{array}$ http://www.cimaglobal.com/Documents/Thought_leadership_docs/Management and financial accounting/Management-accounting-support-of-strategic-management-process.pdf

Huafang, X., \& Jianguo, Y. (2007). Ownership structure, board composition and corporate voluntary disclosure. Managerial Auditing Journal, 22(6), 604-619. http://doi.org/10.1108/02686900710759406

Jensen, M. C., \& Meckling, W. H. (1976). Theory of the firm: Managerial behavior, agency costs and ownership structure. Journal of Financial Economics, 3(4), 305-360. http://doi.org/10.1016/0304-405X(76)90026-X

Jiang, H., \& Habib, A. (2009). The impact of different types of ownership concentration on annual report voluntary disclosures in New Zealand. Accounting Research Journal, 22(3), 275-304. http://doi.org/10.1108/10309610911005590

Juras, A. (2014). Strategic Management Accounting - What Is the Current State of the Concept? Economy Transdisciplinarity Cognition, 17(2), 76-83.

Langfield-Smith, K. (2008). Strategic management accounting: how far have we come in 25 years? Accounting, Auditing \& Accountability Journal, 21(2), 204-228. http://doi.org/10.1108/09513570810854400

Lukviarman, N. (2001). Key characteristics of corporate governance: The case of Indonesia (No. 1).

Ma, Y., \& Tayles, M. (2009). On the emergence of strategic management accounting: An institutional perspective. Accounting and Business Research, 39(5), 473-495. http://doi.org/10.1080/00014788.2009.9663379

Nagar, V., Nanda, D., \& Wysocki, P. (2003). Discretionary disclosure and stock-based incentives. Journal of Accounting and Economics, 34(1-3), 283-309. http://doi.org/10.1016/S0165-4101(02)00075-7

Nixon, B., \& Burns, J. (2012). The paradox of strategic management accounting. Management Accounting Research, 23(4), 229-244. http://doi.org/10.1016/j.mar.2012.09.004

Probohudono, A. N. (2012). A comparative analysis of voluntary risk disclosures. Curtin University. Retrieved from http://hdl.handle.net/20.500.11937/2132

Probohudono, A. N., Vu, K. A., \& Mustika, T. M. (2014). Risk reporting practices by the aviation industry. Corporate Ownership and Control, 12(1-4), 438-449. http://doi.org/10.22495/cocv12i1c4p7

Rahmawati, S., Agustiningsih, S. W., \& Setiany, E. (2015). The effect of earnings management with special item to investment decision: empirical study at manufacture firm listed in Indonesia Stock Exchange 2008-2010. International Journal of Monetary Economics and Finance, 8(2), 111-125. http://doi.org/10.1504/IJMEF.2015.070777

Roslender, R., \& Hart, S. J. (2002). Integrating Management Accounting and Marketing in the Pursuit of Competitive advantage: the case for strategic management accounting. Critical Perspectives on Accounting, 13(2), 255-277. http://doi.org/10.1006/cpac.2001.0477

Said, R., Zainuddin, Y. H., \& Haron, H. (2009). The relationship between corporate social responsibility disclosure and corporate governance characteristics in Malaysian public listed companies. Social Responsibility Journal, 5(2), 212-226. http://doi.org/10.1108/17471110910964496

Samaha, K., \& Dahawy, K. (2011). An empirical analysis of corporate governance structures and voluntary corporate disclosure in volatile capital markets: the Egyptian experience. International Journal of Accounting, Auditing and Performance Evaluation, 7(1/2), 61-93. http://doi.org/10.1504/IJAAPE.2011.037726

Shank, J. K. (1989). Strategic cost management: new wine, or just new bottles? Journal of Management Accounting Research, 1, 47-65.

Simmonds, K. (1981). Strategic management accounting. Management Accounting (UK), 59(4), 26-29. 
Suteja, J., \& Gunardi, A. (2016). CSR disclosure, corporate fundamental factors, corporate governance and profitability of banks in Indonesia. Social Sciences (Pakistan), 11(19), 4672-4676. http://doi.org/10.3923/sscience.2016.4672.4676

Tillmann, K., \& Goddard, A. (2008). Strategic management accounting and sense-making in a multinational company. Management Accounting Research, 19(1), 80-102. http://doi.org/10.1016/j.mar.2007.11.002

Vu, K. A., Tower, G., \& Scully, G. (2011). Corporate communication for Vietnamese listed firms. Asian Review of Accounting, 19(2), 125-146. http://doi.org/10.1108/13217341111181069

Ward, K. (1992). Strategic management accounting. Oxford: Butterworth-Heinemann.

Yuen, C. Y. D., Steven, Z. X., Morris, L. M., \& Lu, V. C. (2010). A Case Study of Voluntary Disclosure by Chinese Enterprises. Asian Journal of Finance and Accounting, 1(2), 118-145. http://doi.org/10.5296/ajfa.v1i2.121 